\begin{tabular}{|c|c|c|c|c|}
\hline JURNAL & \multirow{2}{*}{ VOLUME 1 } & \multirow{2}{*}{ NOMOR 2 } & \multirow{2}{*}{ HALAMAN 70-141 } & $\begin{array}{l}\text { ISSN 2655-8823 }(p) \\
\text { ISSN 2656-1786 }(e)\end{array}$ \\
\hline
\end{tabular}

\title{
PERAN POLITIK CEU POPONG DALAM MEMBANGUN BANGSA YANG HARMONI
}

\author{
Rd. Dewi Ismawati \\ Mahasiswa Program Magister Administrasi Publik, Universitas 17 Agustus 1945 \\ E-mail: dewisaghay@gmail.com \\ Rohadi \\ Kepala Program Prodi Magister Administrasi Publik, Universitas 17 Agustus 1945 \\ E-mail: rohadin17845@ untagcirebon.ac.id \\ Soni Akhmad Nulhaqim \\ Departemen Kesejahteraan Sosial FISIP UNPAD \\ E-mail:soni.nulhaqim@unpad.ac.id
}

\begin{abstract}
ABSTRAK
Kebudayaan dan gender tidak dapat dipisahkan. Dalam budaya Sunda, kedudukan perempuan dalam wilayah domestik maupun di luar bisa menjadi kontradiktif. Ceu Popong sebagai perempuan asli Sunda membuktikan bahwa, terlepas dari beragam persepsi bagaimana budaya Sunda dalam memandang kedudukan perempuan, ia tetap bisa mengembangkan diri sebagai politisi hingga terpilih menjadi Anggota DPR-RI selama lima periode. Dalam perspektif teori gender dan gerakan feminis, perubahan peran Ceu Popong sebagai pengurus rumah tangga menjadi politisi membuktikan pentingnya pendidikan dan keadilan sosial sebagai kunci pemberdayaan perempuan, khususnya di ranah politik praktis. Ceu Popong juga telah membuktikan identitas pribadi, seperti gender, suku, atau bahkan partai, merupakan salah satu dari banyak faktor untuk membangun harmoni bangsa dalam keberagaman.
\end{abstract}

Kata Kunci: Ceu Popong, perempuan, kebudayaan, Sunda

\begin{abstract}
The concept of culture and gender cannot be separated. In Subdanese culture, women position in domestic and public area can be contradictive. Ceu Popong as Sundanese woman proves that, regardless the varies perception of women position in Sundanese culture, she can actualize her role as politicianand got elected as member of parliament (DPRRI) for five periods. Gender theory and feminism movement theory, explained this role changes from householf wife to politician is a proof of the importance of education and social justice as the keys to women empowerment, especially in political sphere. And also. Ceu Popong has proved that personal identity, like gender, culture, and even party, are one of many factors that can build nations's harmony in diversity.
\end{abstract}

Keywords: Ceu Popong, women, culture, Sundanese

\section{PENDAHULUAN}

Kebudayaan dan gender tidak dapat dipisahkan. Bagaimana kedudukan perempuan Sunda dalam wilayah domestik maupun di luar bisa menjadi kontradiktif. Seorang perempuan yang memegang teguh adat istiadatnya dalam masyarakat patriarki biasanya tidak dapat mengembangkan diri di luar wilayah domestik, terlebih lagi di era Orde Baru yang otoriter. Adanya sosok Ceu Popong yang sudah aktif sebagai politisi Golkar yang menduduki kursi Anggota DPRRI di tahun 1964 dan kembali terpilih sampai lima periode merupakan fenomena yang unik. Peran Ceu Popong sebagai perempuan Sunda dengan empat orang anak, tidak menghalanginya untuk terjun di dunia politi praktis. Tulisan ini berusaha untuk menganalisis dan menjelaskan bagaimana peran politik Ceu Popong dari perspektif budaya Sunda dan juga dari perspektif gender. Dalam tulisan ini akan dijelaskan terlebih dahulu konsep kebudayaan, kebudayaan Sunda, dan kedudukan perempuan dalam budaya Sunda, untuk memberi gambaran konsep kebudayaan secara umum dan bagaimana konstruksi sosial perempuan dalam budaya Sunda. Selain itu tulisan ini juga akan menggunakan teori gender dan gerakan feminis untuk menganalisis bagaimana perubahan peran perempuan di tengah budaya masyarakat 
patriarki. Perspekstif gender juga digunakan unntuk menjelaskan bagaimana Ceu Popong menjadi contoh sosok perempuan yang bisa mengembangkan dirinya di luar wilayah domestik.

\section{KONSEP KEBUDAYAAN}

Ada beberapa pendapat mengenai pengertian dan asal mula kata budaya. Menurut Warsito, budaya adalah kependekan kata dari budi dan daya yang berarti cinta, karsa dan rasa. Dikatan juga budaya berasal dari bahasa Sansekerta budhayah yang merupakan bentuk jamak dari buddhi yang berarti budi atau akal. Karenanya, budaya berkaitan dengan konsep akal. Pendapat lain mengungkapkan kata budaya sebagai bentuk majemuk budidaya yang berarti daya dari budi atau kekuatan dari akal. Pendepat demikian membedakan antara budaya dengan kebudayaan. Menurut Warsito, dalam Antropologi budaya, budaya dan kebudayaan dianggap sama.

Kata budaya merupakan bentuk pendek dari kebudayaan, dengan makna yang sama. ${ }^{1}$ Soemarjan dan Soelaiman, dikutip dalam Hartono dan Aziz, memberikan batasan kebudayaan sebagai semua hasil karya rasa dan cipta masyarakat. ${ }^{2}$ Secara konseptual, budaya didefinisikan sebagai tatanan pengetahuan, pengalaman, kepercayaan, nilai, sikap, makna, hierarki, waktu, peranan, hubungan ruang, konsep alam semesta, objekobjek materi, dan kepemilikan yang diperoleh sekelompok orang diturunkan dari generasi ke generasi melalui usaha individu dan kelompok. Kebudayaan berkaitan dengan aspek kehidupan seperti cara berperilaku, kepercayaan, sikap dan hasil daya manusia yang khas pada masyarakat atau kelompok tertentu. Kebudayaan manusia terus berkembang, dengan berjalannya waktu pola pikir dan hidup

\footnotetext{
${ }^{1}$ Drs. H. R. Warsito, M.Pd., Antropologi Budaya, Cet II (Yogyakarta: Ombak, 2015), h. 48-49.

${ }^{2}$ H. Hartono dan Arnicun Aziz, Ilmu Sosial Dasar, (Jakarta: Bumi Aksara, 2008), h. 38.
}

manusia akan berubah. Perkembangan itu merupakan hasil dari proses sosialisasi, ketika manusia menerima kebudayaan di tempat kelahirannya. Banyak antropolog berpendapat proses ini merupakan proses pewarisan kebudayaan generasi ke generasi selanjutnya.

Menurut Setiadi, kendati tiap kebudayaan tidaklah sama, seperti di Indonesia yang terdiri dari berbagai suku bangsa dan budaya yang berbeda, tetapi setiap kebudayaan mempunyai ciri atau karakter yang sama. ${ }^{3}$ Sifat-sifat budaya itu akan memiliki ciri-ciri yang sama bagi semua kebudayaan manusia tanpa membedakan faktor ras, lingkungan alam, atau pendidikan. Disebut juga sifat hakiki yang berlaku umum bagi semua budaya di manapun. Sifat hakiki dari kebudayaan antara lain: (a) Budaya diejawantahkan dalam perilaku manusia; (b) Budaya sudah ada dari sebelum lahirnya suatu generasi tertentu dan tidak akan hilang bersamaan dengan habisnya generasi tersebut; (c) Budaya diperlukan oleh manusia; (d) Budaya memiliki aturan-aturan yang berisikan kewajiban-kewajiban, tindakan-tindakan yang diterima dan ditolak, tindakan-tindakan yang dilarang dan diizinkan.

\section{BUDAYA SUNDA}

Istilah Sunda, dikatakan Ekadjati, merujuk pada wilayah di bagian barat Pulau Jawa dengan segala aktivitas kehidupan manusia di dalamnya. Pada awalnya istilah Sunda muncul pada abad ke-9 M. ${ }^{4}$ Istilah tersebut tertulis dalam prasasti yang ditemukan di Kebonkopi, Kabupaten Bogor. Dalam perkembangannya, istilah Sunda digunakan juga dalam menyebut manusia atau kelompok manusia, yaitu sebutan "orang Sunda" (urang Sunda dalam bahasa Sunda). Orang Sunda adalah orang yang mengaku dirinya dan diakui oleh orang lain

\footnotetext{
${ }^{3}$ Elly M. Setiadi, Kama Abdul Hakam, dan Ridwan Effendi, Ilmu Sosial dan Budaya Dasar, (Jakarta: Kencana, 2008), h. 33-34.

4 Edi S. Ekadjati, Kebudayaan Sunda: Suatu Pendekatan Sejarah Jiid 1, (Jakarta: PT Dunia Pustaka Jaya, 2009), h. 2
} 


\begin{tabular}{|c|c|c|c|c|}
\hline JURNAL & \multirow{2}{*}{ VOLUME 1 } & \multirow{2}{*}{ NOMOR 2 } & HALAMAN 70-141 & $\begin{array}{l}\text { ISSN 2655-8823 }(p) \\
\text { ISSN 2656-1786 }(e)\end{array}$ \\
\hline
\end{tabular}

sebagai orang Sunda. Definisi menyiratkan kriteria berdasarkan keturunan (hubungan darah) dan juga berdasarkan sosial budaya.

Budaya Sunda, dikemukakan oleh Edi S. Ekadjati, merupakan budaya yang hidup, tumbuh, dan berkembang di kalangan orang Sunda pada umumnya yang hidup di pulau Jawa bagian barat. Kebudayaan Sunda dalam tata sosial budaya bangsa Indonesia digolongkan sebagai kebudayaan daerah. ${ }^{5}$ Menurut Ajip Rosyidi, kebudayaan Sunda terlahir dari manifestasi gagasan, fikiran, dan kegiatan yang dilakukan oleh orang-orang terdahulu baik itu berupa sesuatu yang abstrak ataupun yang berbentuk zahir, yang dilakukan oleh sekelompok manusia yang menyebut dirinya sebagai orang Sunda. ${ }^{6}$

\section{KEDUDUKAN PEREMPUAN DALAM BUDAYA SUNDA}

Kata kedudukan, didefinisikan oleh Soekanto, meiliki arti tempat seseorang dalam suatu pola tertentu. Bila seseorang memiliki beberapa kedudukan artinya orang itu ikut serta dalam beberapa pola kehidupan. "Kedudukan (status) merupakan suatu perangkat atau posisi seseorang dalam suatu kelompok dan hubungannya dengan kelompok lain dalam masyarakat."7

Menurut Suryaman dikutip dalam Marlina, struktur kekerabatan masyarakat Sunda bersifat bilateral (parental) artinya laki-laki dan perempuan mempunyai kewajiban dan hak yang sama dalam sistem kekerabatan. ${ }^{8}$ Semua anak laki-laki dan perempuan mendapat hak waris baik dari pihak ayah maupun dari pihak ibu. Namun pada praktiknya, terjadi perbedaan perlakuan terhadap laki-laki dan perempuan, di mana perempuan dinomor duakan. Hal ini disebabkan dalam keluarga Sunda selalu

\footnotetext{
5 Edi S. Ekadjati, Kebudayaan Sunda: Suatu Pendekatan Sejarah Jiid 1, (Jakarta: PT Dunia Pustaka Jaya, 2009), h. 8.

${ }^{6}$ Ajip Rosyidi, Masa Depan Budaya Daerah: Kasus Bahasa Sunda dan Sejarah Sunda, (Jakarta: PT Dunia Pustaka Jaya, 2004) h. 29.

${ }^{7}$ Soerjono Soekanto, Teori Sosiologi tentang Pribadi dalam Masyarakat, (Jakarta: Ghalia Indonesia, 4), h. 41
}

menempatkan ayah (laki-laki) sebagai kepala keluarga dan bertanggung jawab dan sebagai pencari nafkah utama dalam keluarganya. Anak laki-laki, terutama anak laki-laki tertua, dianggap sebagai pengganti kedudukan ayah, jika ayah berhalangan. Anak lelaki mendapat bagian warisan orang tuanya dua kali dari pada bagian warisan yang diterima anak perempuan.

Ditinjau dari kacamata kebudayaan dan perspektif historis, kedudukan perempuan Sunda dalam struktur masyarakat bervariasi seperti tercermin data sosial budayanya. Marlina 9 menjelaskan kedudukan perempuan dalam budaya Sunda berbedabeda. Kedudukan perempuan berdasarkan cerita tradisi lisan dan tradisi tulisan sangat bervariatif bahkan kontradiktif yaitu ada yang tinggi, rendah, netral, dan kuat. Pada satu budaya kesusastraan lisan, kedudukan kaum perempuan itu digambarkan dapat menuntut kepada kaum laki-laki dalam rangka mempertahankan kehormatannya, seperti digambarkan dalam cerita Sangkuriang. Di sini Dayang Sumbi menuntut syarat-syarat perkawinan demi mempertahankan kehormatan dirinya. Dalam kisah lain, perempuan Sunda itu digambarkan mempunyai kedudukan terhormat dan tinggi, bahkan lebih tinggi dari laki-laki, seperti dilukiskan dalam pantun Lutung Kasarung. Dalam hal ini Sunan Ambu adalah penguasa di alam kahyangan, sedangkan ratu Purbasari berkuasa di kerajaan (dunia). Dalam tradisi tulisan yang lahir pada abad ke-19 (Wawacan Sajarah Galuh) dan awal abad ke-20 (Wawacan Carios Munada) justru kedudukan perempuan Sunda digambarkan sangat rendah dan berada di bawah kuasa laki-laki.

\footnotetext{
8 Marlina, Hj. Ietje, "Kedudukan Wanita Menak Dalam Struktur Masyarakat Sunda: Studi Kasus di Kota Bandung," Sosiohumaniora, Vol. 8, No. 2, Juli 2006 h. 189

9 Marlina, Hj. Ietje, "Kedudukan Wanita Menak Dalam Struktur Masyarakat Sunda: Studi Kasus di Kota Bandung," Sosiohumaniora, Vol. 8, No. 2, Juli 2006 h. 190
} 


\begin{tabular}{|c|c|c|c|c|}
\hline JURNAL & \multirow{2}{*}{ VOLUME 1 } & \multirow{2}{*}{ NOMOR 2 } & HALAMAN 70-141 & $\begin{array}{l}\text { ISSN 2655-8823 }(p) \\
\text { ISSN 2656-1786 }(e)\end{array}$ \\
\hline
\end{tabular}

\section{TEORI GENDER}

Konsep gender biasanya dimaknai sebagai pemisahan manusia ke dalam dua jenis yakni perempuan dan laki-laki. Padahal jika ditinjau lebih lanjut, pemaknaan seperti itu sama dengan konsep sex (jenis kelamin), padahal keduanya memiliki pemaknaan yeng berbeda. Gender adalah pemisahan katagori perempuan dan laki-laki berdasarkan konstruksi sosial, berkaitan dengan peran, sifat, tanggung jawab, nilai, perilaku, mentalitas, dan karakteristik emosional atas kedua jenis kelamin tersebut. ${ }^{10}$

Pembedaan atas gender ini seringkali menimbulkan ketidakadilan dalam banyak aspek sosial. Contohnya ketika perempuan bekerja mereka biasanya mendapat upah lebih sedikit dibanding dengan laki-laki, dan biasanya ditempatkan di wilayah yang dianggap bisa dikerjakan oleh perempuan sebagai makhluk yang secara fisik dianggap lemah. Kemudian ada beban ganda (double burden) yang diterima perempuan ketika ia memutuskan untuk bekerja ia juga tidak boleh melupakan yang menurut sebagian besar budaya masyarakat adalah tugas utama dan pokok dari perempuan utamanya yang sudah berkeluarga yakni mengurus urusan domestik seperti urusan keluarga dan rumah, serta masih banyak ketidakadilan lainnya yang diterima oleh perempuan. ${ }^{11}$

Berbicara tentang gender tentu saja tak terlepas dari membincangkan ketidakadilan pada perempuan yang terdapat di dalam masyarakat baik masyarakat tradisonal, maupun modern sekalipun melingkupi banyak ruang privat dan publik, ruang privat biasa dikenal dengan institusi keluarga, sedangkan ruang publik ada berbagai macam wilayahnya tidak terkecuali dalam hal politik. Ketidakadilan dalam keluarga terletak pada diposisikannya perempuan

\footnotetext{
${ }^{10}$ Ida Rosyidah dan Hermawati, Relasi Gender dalam Agama-Agama (Jakarta: UIN Jakarta Press), h. 13

${ }^{11}$ Mansour Fakih, Analisis Gender dan Transformasi Sosial (Yogyakarta: Pustaka Pelajar, 1997), h. 150

12 Ian Adams, Ideologi Politik Mutakhir: Konsep, Ragam, Kritik, dan Masa Depannya (Yogyakarta: Qalam, 2004), h. 381.
}

(ibu/isteri) dibawah dari laki-laki (ayah/suami).

Kondisi asimetris yang dialami perempuan tidak hanya dirasakan di ruang privat atau domestik saja, tetapi juga banyak terjadi di ruang public. Seperti dalam ranah politik, perempuan sering terpinggirkan secara halus dengan justifikasi stereotipe dan konstruksi sosial di masyarakat yang menyatakan bahwa perempuan akan lebih baik dan berguna bila hanya mengurusi keluarga (privat) dan sebisa mungkin tidak mempunyai banyak peranan di luar (publik). Karena dengan peran publik perempuan dianggap membuat konsentrasinya terpecah antara salah satu ruang privat atau publik. Karena itu perempuan sering mendapat peran lebih rendah (subordinat), yang terbatas sebagai ibu rumah tangga dan terasing dalam urusan publik. ${ }^{12}$

Ideologi liberal adalah ideologi yang pertama-tama mendukung gerakan kesetaraan dan keadilan yang dituntut oleh kaum perempuan, untuk selanjutnya gerakan ini disebut gerakan feminis. Para pendukung feminis dengan sudut pandang liberal berasumsi bahwa agar tercipta individu yang otonomi dan independen haruslah didahului dengan terciptanya masyarakat yang adil, maka dari itu kesetaraan dan keadilan pada perempuan atas hak-haknya diperlukan untuk menunjang itu semua. Tujuan umum dari feminisme liberal adalah untuk menciptakan masyarakat yang adil dan peduli tempat kebebasan berkembang. Hanya di dalam masyarakat seperti itu, perempuan dan juga laki-laki dapat mengembangkan diri. ${ }^{13}$ Walau demikian, gerakan feminis pada praktiknya tetap merujuk pada teori yang ditulis oleh ilmuwan-ilmuwan yang mendukung gerakan tersebut, sematamata sebagai panduan untuk arah gerakan selanjutnya.

13 Rosemarie Putnam Tong, Feminist Thought: Pengantar Paling Komprehensif kepada Aliran Utama Pemikiran Feminis, (Yogyakarta: Jalasutra, 2004), h. 16 
Menurut Mansour Fakih, pemikiranpemikiran tentang feminisme terbagi kedalam beberapa aliran yang berbeda satu dengan yang lainnya yakni feminism liberalis, feminisme radikal, feminisme marxis, serta feminisme sosialis. Keempat aliran tersebut menurut Fakih bisa ditelaah dari dua paradigma besar dunia keilmuan sosial yaitu paradigma fungsionalis atau status quo dan paradigm sosiologi-konflik, kedua paradigma ini berkontribusi untuk menjelaskan bagaimana feminisme menjadi aliran yang tak hanya sekadar praktik namun berlandaskan pula pada ranah teori. Dalam tulisan ini hanya akan dijelaskan mengenai gerakan feminis liberal yang dianggap penulis paling menekati fenomena perubahan peran Ceu Popong dari ranah domestik ke ranah public (politik).

Feminisme liberal adalah aliran feminis yang paling dikenal umum di dunia, khususnya negara dunia ketiga (negara berkembang) yang beranggapan bahwa perempuan semestinya diberi kesempatan dan hak yang sama. Jika sudah diberi hak yang sama namun perempuan masih dianggap pasif maka hal demikian adalah kesalahan dari perempuan sendiri, aliran ini merasa perempuan harus diberi pemahaman dan pengetahuan mendalam akan hak dan kesempatannya supaya perempuan dapat mencapai kesetaraan dengan laki laki, namun banyak yang mengkritik aliran ini karena dianggap menafikan budaya patriarki yang membelenggu perempuan menjadi pasif meskipun sudah diberi kesempatan dan haknya. Feminisme liberal beranggapan bahwa sistem patriarki dapat dihilangkan dengan cara mengubah sikap masing-masing individu, terutama sikap kaum perempuan dalam hubungannya dengan laki-laki. Perempuan harus sadar dan menuntut hakhaknya. Beberapa persoalan yang dituntut

\footnotetext{
14 Rosemarie Putnam Tong, Feminist Thought: Pengantar Paling Komprehensif kepada Aliran Utama Pemikiran Feminis, (Yogyakarta: Jalasutra, 2004), h. 17

15 Rosemarie Putnam Tong, Feminist Thought: Pengantar Paling Komprehensif kepada Aliran Utama
}

kesetaraannya pada masa-masa awal gerakan feminisme adalah masalah pendidikan dan upah buruh perempuan. Berlanjut pada abad ke-19 dengan hak-hak politik seperti memilih pada pemilu. ${ }^{14}$ Tokoh tokoh feminisme liberal, Mary Wollstonecraft, berpendapat menyangkal adanya pandangan bahwa kondisi alamiah perempuan menyebabkan perempuan kurang memiliki intelektualitas dan kemampuan fisik seperti laki-laki. Agar perempuan dapat berkembang seperti lakilaki, maka perempuan harus berpendidikan sama seperti lakilaki. Kesetaraan dan kesamaan perlakuan antara perempuan dan laki-laki menjadi dasar pemikiran Wollstonecraft yang cenderung antimainstream pada zamannya.

Dengan adanya pendidikan bagi perempuan maka perempuan diharapkan bisa mandiri dari laki-laki. Hal ini menurut Wollstonecraft dapat menghilangkan pandangan perempuan hanya sebatas objek bukan manusia yang mempunyai nilai lebih. Satu abad setelah gagasan feminisme liberal Wollstonecraft hadir, muncul pula gagasan dari John Stuart Mill dan Harriet Taylor yang menulis dan melanjutkan apa yang dicitakan oleh Wollstonecraft. Mill dan Taylor meyakini bahwa jika masyarakat ingin mencapai kesetaraan seksual, atau keadilan gender, maka masyarakat harus memberi perempuan hak politik dan kesempatan, serta pendidikan yang sama yang dinikmati oleh laki-laki seperti kata Wollstonecraft. ${ }^{15}$

\section{PROFIL CEU POPONG}

Dr. (H.C.) Dra. Hj. Popong Otje Djundjunan atau biasa dikenal dengan panggilan Ceu Popong (Сеисеu berarti kakak perempuan dalam Bahasa Sunda ${ }^{16}$ ) ialah politisi senior dari Partai Golongan Karya atau Partai Golkar. Menurut buku autobiografinya, ibu dari empat orang anak,

Pemikiran Feminis, (Yogyakarta: Jalasutra, 2004), h. 22

16 Tanpa nama penulis, "Panggilan kepada kakak perempuan," Kamusdaerah.com, https://www. kamusdaerah.com/?bhs=a\&bhs2=m\&q=panggilan $\% 2$ 0kepada\%20kakak\%20perempuan, diakses pada 5 Juli 2019. 


\begin{tabular}{|c|c|c|c|c|}
\hline JURNAL & \multirow{2}{*}{ VOLUME 1 } & \multirow{2}{*}{ NOMOR 2 } & HALAMAN 70-141 & $\begin{array}{l}\text { ISSN 2655-8823 }(p) \\
\text { ISSN 2656-1786 }(e)\end{array}$ \\
\hline
\end{tabular}

lahir di Bandung pada 30 Desember 1938 (saat ini berusia 80 tahun) dengan nama Popong Kurniasih, merupakan lulusan Universitas Pendidikan Indonesia pada tahun 1963 dan pernah berkecimpung di dunia pendidikan sebagai guru Bahasa Inggris. ${ }^{17}$ Ceu Popong ialah istri dari Rd. Otje Djundjunan yang merupakan anggota TNI $\mathrm{AD}$ dan pernah menjabat sebagai walikota Bandung periode 1971-1976. Sebagai istri seorang anggota TNI AD dan walikota Bandung, menjadikan Ceu Popong akrab dengan pergaulan militer dan politisi. Melalui Partai Golkar di Daerah Pemilihan Barat I, ia telah menduduki kursi anggota Dewan Perwakilan Rakyat Republik Indonesia

(DPR-RI) selama lima periode sejak 1987, yaitu pada periode 1987-1992, periode 19921997, periode $1997-1999$, periode 2009 2014, dan saat ini sedang menjabat pada periode 2014-2019. Saat ini Ceu Popong tercatat sebagai Anggota DPR-RI tertua yang masih aktif memerhatikan isu-isu pendidikan dan kebudayaan di Komisi X DPR-RI. ${ }^{18}$

Selama perjalanannya sebagai politisi Partai Golkar dan Anggota DPR-RI, Ceu Popong dikenal vokal terhadap isu dan kebijakan pendidikan. Ujian Nasional (UN) merupakan salah satu isu yang ia kritisi karena dianggap tidak tepat dijadikan satusatunya penentu kelulusan siswa. Pada tahun 2016 ia juga mendukung Menteri Pendidikan dan Kebudayaan, Muhadjir Effendy, untuk menghapus UN. Kebijakan

\footnotetext{
${ }^{17}$ Popong Otje Djundjunan, Autobiografi Popong Otje Djundjunan (Jakarta: 2019)

18 Tanpa nama penulis, "Dra. Popong Otje Djundjunan," Dewan Perwakilan Rakyat Republik Indonesia, http://www.dpr.go.id /anggota/detail/id/100

19 Raja Eben Lumbanrau, "Ceu Popong Dukung Putusan Mendikbud Muhadjir Hapus UN 2017," CNN Indonesia, 25 November 2016, diakses dari https://www.cnnindonesia.com/nasional/2016112516 0746-175295/ceu-popong-dukung-putusanmendikbud-muhadjir-hapus-un-2017, diakses pada 5 Juli 2019.

${ }^{20}$ Tanpa nama penulis, "Popong Otje Djundjunan", Merdeka.com, https://m.merdeka.com/popongotjedjundjunan/profil/, diakses pada 5 Juli 2019.
}

UN dinilai tidak adil mengingat kualitas pendidikan di Indonesia dari Sabang sampai Merauke belum merata. ${ }^{19}$ Selain isu UN, Ceu Popong juga vokal mengkritisi penggunaan istilah dan Bahasa Asing oleh pejabat negara. Menurutnya, alangkah baiknya jika pejabat negara menggunakan istilah bahasa negeri sendiri ketimbang bahasa Inggris. ${ }^{20}$ Sikap kritisnya terhadap UN dan penggunaan istilah asing oleh pejabat negara didasari atas perannya di Komisi $\mathrm{X}$ yang menangani Budaya dan Peradaban sehingga sudah selayaknya orangorang yang berada di komisi tersebut kritis terhadap hal-hal semacam itu. ${ }^{21}$

Selain memegang rekor sebagai Anggota DPR-RI paling senior yang masih aktif, Ceu Popong juga memegang rekor sebagai Anggota DPR-RI dengan penghargaan palang banyak. Tercatat sudah 506 penghargaan yang diterima Ceu Popong yang juga dikukuhkan melalui Museum Rekor Indonesia (MURI). ${ }^{22}$ Penghargaan yang diterima Ceu Popong termasuk gelar Doktor Honoris Causa dari alma maternya, Universitas Pendidikan Indonesia (UPI), Bandung. Ia menerika gelar Doktor Honoris Causa dalam bidang kebudayaan karena diaggap aktif dalam pelestarian budaya, khususnya budaya Sunda, sebagai politisi.

\section{PERAN POLITIK CEU POPONG}

Dalam wawancara ${ }^{23}$ yang dilakukan penulis dengan Ceu Popong diungkapkan bahwa Ceu Popong sudah mulai terjun ke dua

\footnotetext{
21 Tanpa nama penulis, "Kisah Ceu Popong tolak menteri pidato bahasa asing," Merdeka.com, 2 Oktober 2014, https://www.merdeka .com/peristiwa/kisah-ceu-popong-tolak-menteripidato-bahasaasing.html, diakses pada 5 Juli 2019 22 "Ceu Popong Raih Penghargaan ke-506," PRFMNews.com, 11 Februari 2017, http://www.prfmnews .com/berita.php?detail=ceupopong-raih-penghargaan-ke506, diakses pada 5 Juli 2019

Wawancara dilakukan di Bandung, pada Jumat, 21 Juni 2019

${ }^{23}$ Wawancara dilakukan di Bandung, pada Jumat, 21 Juni 2019
} 


\begin{tabular}{|c|c|c|c|c|}
\hline JURNAL & \multirow{2}{*}{ VOLUME 1 } & \multirow{2}{*}{ NOMOR 2 } & \multirow{2}{*}{ HALAMAN 70-141 } & $\begin{array}{l}\text { ISSN 2655-8823 }(p) \\
\text { ISSN 2656-1786 }(e)\end{array}$ \\
\hline
\end{tabular}

politik sejak Tentara Nasional Indoensia (TNI), khususnya TNI Angkatan Darat mendirikan Golonga Karya (Golkar), pada 20 Oktober 1964, yang pada saat itu statusnya bukan merupakan partai politik tetapi memiliki peran yang sama dengan partai politik. Dengan berdirinya sekretariat bersama Golkar maka para istri diwajibkan untuk berkontribusi pada Golkar, minimal mengenal apa dan bagaimana peran Golkar dalam pemerintahan. Saat itu Ceu Popong sebagai istri dari prajurit TNI, harus bergabung dengan dengan Golkar. Partisipasi Ceu Popong dalam Golkar bukan merupakan hal yang asing baginya. Ceu Popok menjelaskan kalau dirinya suka berorganisasi sejak masih berada di bangku sekolah. Maka itu, ketika Golkar didirikan dan istri prajurit TNI wajib berpartisipasi, ia tidak ragu-ragu untuk langsung terjun ke dua politik Golkar.

Pada saat Golkar didikan di masa Orde Baru, partisipasi perempuan dalam politik praktis masih sangat minim. Suhud Warnaen, tokoh nasional yang pernah menjadi Wakil Gubernur Jawa Barat, yang sudah dianggap sebagai kakak sendiri oleh Ceu Popong, memintanya agar mau dicalonkan menjadi anggota DPR-RI. Soehoed Warnaen mengungkapkan kalau Ceu Popong memiliki potensi untuk posisi tersebut. Pertimbangan lain mengapa $\mathrm{Ceu}$ Popong bersedia untuk dicalonkan menjadi Anggota DPR-RI adalah mengingat semua anak Ceu Popong sudah masuk ke bangku kuliah dan anak-anaknya tidak berkeberatan, sehingga tanggung jawab dan peran Ceu Popong di wilayah privat sudah berkurang. Setelah pertimbangan tersebut, Ceu Popong dicalonkan dan terpilih menjadi anggota DPR-RI pada tahun 1987.

Dengan pengalaman Ceu Popong di bidang politik praktis yang masih minim, ia sadar harus belajar banyak. Ceu Popong menyadari ia tidak memiliki pengalaman sebelumnya sebagai anggota DPR tingkat daerah apa lagi DPR-RI, oleh karenanya Ceu Popong lebih banyak membaca, mengamatii, dan bertanya dengan tokoh-tokoh yang lebih berpengalaman untuk dapat menjalankan perannya di DPR-RI dengan baik.
"Niatnya adalah bagaimana untuk bisa melaksanakan sebagai wakil rakyat yang baik"

Pengalaman menjadi Anggota DPR-RI selama lima periode di masa Orde Baru dan Orde Reformasi, sudah banyak pengalaman yang Ceu Popong dapatkan dalam dunia politik nasional. Peran yang langkah yang ia ambil sebagai Anggota DPR-RI juga berbeda di masa Orde Baru dan Orde Reformasi. Ceu Popong megungkapkan, pada masa Orde Baru, Anggota DPR-RI memiliki budaya yang disiplin dan tepat waktu. Terlebih lagi adanya Fraksi ABRI (Angkatan Bersenjata Republik Indonesia) yang memberi contoh kedisiplinan kepada anggota dari kalangan sipil. Namun demikian, pada masa Orde Baru, peran DPR-RI tidak signifikan, Anggota DPR-RI tidak bisa banyak memberi usul kepada Pemerintah. Selain itu mengingat Ceu Popong berada di Fraksi Golkar yang berperan mendukung Pemerintah di dalam DPR. Ketika itu anggota memberi interupsi di tengah rapat atau sidang merupakan hal yang tabu. Tetapi dalam situasi seperti itu Ceu Popong memiliki pengalaman menarik. Ketika itu Ceu Popong memberikan interupsi di dalam sidang MPR yang dipimpin oleh Akbar Tandjung dan Ginandjar Kartasasmita. Pada sidang tersebut Ceu Popong sebagai anggota sidang menemukan ada hal yang keliru dalam rapat dan memberikan interupsi. Keesokan harinya interupsi Ceu Popong dalam sidnag MPR menjadi berita utama di koran kalau ada anggota yang memberi interupsi di tengah sidang.

\section{PERAN CEU POPONG SEBAGAI PEREMPUAN SUNDA}

Berkaitan dengan sosok Ceu Popong sebagai perempuan Sunda, ia mengungkapkan ada banyak nasihat dari budaya Sunda berkaitan dengan pengembangan diri. Pengetahuannya mengenai nasihat dari budaya Sunda bukan hanya karena ia merupakan keturunan Sunda asli, tetapi juga karena ia gemar membaca dan banyak membaca mengenai filosofi- 


\begin{tabular}{|c|c|c|c|c|}
\hline JURNAL & \multirow{2}{*}{ VOLUME 1 } & \multirow{2}{*}{ NOMOR 2 } & HALAMAN 70-141 & $\begin{array}{l}\text { ISSN 2655-8823 }(p) \\
\text { ISSN 2656-1786 }(e)\end{array}$ \\
\hline
\end{tabular}

filosofi budaya Sunda. Ceu Popong menjelaskan, mayoritas filosofi budaya Sunda merupakan filosofi yang baik untuk dirinya, tetapi ada pula beberapa filosofi yang dianggap kurang baik. Di antara contoh yang kurang baik adalah "kumaha engke wae" (gimana nanti saja), menurutnya seharusnya adalah "engke kumaha" (nanti bagaimana). Tetapi lebih banyak filosofi Sunda yang baik, di antara yang menjadi pegangannya adalah "silih asah silih asih silih asuh." Silih asah artinya saling menajamkan pikiran atau saling mengingatkan. Silih asih artinya saling mengasihi. Silih asuh artinya saling mengasuh atau saling membimbing. Filosofi Sunda yang lain yang diamalkan oleh Ceu Popong adalah "someah hade kasemah" yang berarti harus tersenyum dan ramah kepada tamu yang datang. Filosofi someah hade kasemah ini juga yang menjadi kunci membangun relasi yang baik di tengah pergaulan politik praktis yang didalami oleh Ceu Popong. Penjelasan Ceu Popong ini sejalan dengan konsep budaya Sunda yang dijelaskan oleh Marlina pada bab sebelumnya. Marlina ${ }^{24}$ menjelaskan budaya Sunda memiliki pandangan yang berbedabeda mengenai filosofi kehidupan, terutama berkaitan dengan kedudukan perempuan. Filososi yang berbeda-beda ini tercermin dalam budaya lisan dan kisah klasik budaya Sunda.

Sebagai perempuan Sunda yang sukses, Ceu Popong membagikan nilai-nilai kunci kesuksesannya. Pertama, "anda adalah apa yang anda katakana." Maksudnya adalah agar kita senantiasa menjaga lisan, harus sopan denga siapa saja dan tidak sembarangan berucap. Kedua, Bagi Ceu Popong, semua suku bangsa punya kelebihan sendiri-sendiri, sehingga jangan sampai menggap suku sendiri lebih baik dari suku lainnya di Indonesia.

Ceu Popong menjelaskan:

"Di manapun kita berada, sebagai apapun kita, dengan siapapun kita berhadapan, tetap di dalam ruh $\mathrm{Ceu}$
Popong tugas kita adalah membuktikan bahwa wanoja Sunda teh aya nu alus."

Ketiga, sebagai orang Sunda kita harus nyantri. Yang dimaksud Ceu Popong dengan nyantri adalah belajar agama. Menurut $\mathrm{Ceu}$ Popong, orang Sunda sudah nyantri atau sudah bersikap Islami dari sebelum Islam masuk ke Nusantara, karena sebelum Islam masuk ke Nusantara leluhur orang Sunda sudah percaya kepada Sanghyang Tunggal, yaitu Tuhan Yang Maha Esa. Menurutnya leluhur sudah mengenal konsep Tuhan Yang Maha Esa yang merupakan konsep dasar dari Islam yaitu tauhid dan tidak menyembah batu atau berhala. Keempat, orang Sunda harus nyakola atau belajar. Belajar yang dimaksud bukan hanya belajar formal di sekolah atau bangku kuliah, tetapi termasuk belajar tata krama kepada orang lain dan orang yang lebih tua. Kelima, Jangan membangga-banggakan apa yang telah kita berikan kemarin, tapi kita hanya diminta untuk memikirkan apa yang bisa kita berikan besok. Prinsil ini merupakan pelajaran yang Ceu Popong ambil dari ajaran Konghuchu yang ia baca dari buku. Keenam, orang yang paling penting adalah orang yang pada saat itu ada bersama-sama kita. Bagi Ceu Popong orang yang paling penting bukanlah orang yang ketika ia berapa jauh secara fisik. Sehingga menurutnya orang yang penting adalah orang yang secara fisik berada di dekat dia di saat ini juga.

Sebagai anggota Komisi X DPR-RI yang membidangi Pendidikan dan Kebudayaan, Ceu Popong banyak memberi perhatian lebih pada isu-isu yang berkaitan dengan kebudayaan. Ceu Popong seringkali mengkritik menteri atau pejabat negara yang suka menggunakan istilah asing dalam pidatonya. Menurut Ceu Popong, walaupun ia merupakan perempuan keturunan Sunda asli, tetapi ketika bekerja sebagai anggota DPRRI ia dan pejabat negara lainnya harus menjaga harmoni kebangsaan, salah satunya dengan menggunakan bahasa Indonesia yang baik dalam situasi kenegaraan. Sebagai pribadi, Ceu Popong menjunjung dan

\footnotetext{
${ }^{24}$ Marlina, "Kedudukan Perempuan Menak...," h. 190
} 


\begin{tabular}{|c|c|c|c|c|}
\hline JURNAL & \multirow{2}{*}{ VOLUME 1 } & \multirow{2}{*}{ NOMOR 2} & HALAMAN 70-141 & $\begin{array}{c}\text { ISSN 2655-8823 }(p) \\
\text { ISSN 2656-1786 }(e)\end{array}$ \\
\hline
\end{tabular}

berusaha melestarikan kebudayaan Sunda, tetapi dalam menjalankan perannya sebagai anggota DPR-RI ia tetap menjaga persatuan bangsa dan tidak merasa suku Sunda sebagai suku yang lebih tinnggi dari suku lain di Indonesia. Bahasa Indonesia merupakan lingua franca (kerangka bahasa) yang menyatukan bangsa Indonesia yang terdiri dri beragam suku bangsa dan bahasa. Sehingga penggunaan bahasa Indonesia sebagai bahasa pemersatu bangsa sangatlah penting. Selain itu, pelestarian budaya daerah dan harmoni bangsa harus berjalan bersamaan. Melestarikan budaya daerah tidak untuk memecah belah bangsa, tetapi justru untuk lebih memersatukan perbedaan antar-suku. Berkaitan dengan hal ini Ceu Popong mengatakan:

"Kita (orang Sunda) tidak merasa lebih dibanding perempuan dari suku-suku lain. Kita (Indonesia) teh ada 400 suku bangsa, iya kan? Kalau belum apa-apa kita sudah merasa pang alusna pang hebatna (paling bagus paling hebat) sebagai orang Sunda, nah ya sudah satu nol itu."

Penjelasan Ceu Popong mengenai filisofi Sunda yang ia percayai memeberikan gambaran nyata dari teori yang dijelaskan oleh Merlina bahwa kedudukan perempuan dalam budaya Sunda berbeda-beda. Kedudukan perempuan berdasarkan cerita tradisi lisan dan tradisi tulisan sangat bervariatif bahkan kontradiktif yaitu ada yang tinggi, rendah, netral, dan kuat. Dalam studi peran politik Ceu Popong, cerita bagaimana Ceu Popong pertama kali terjun dalam dua politik sampai ia berperan sebagai Anggota DPRRI menunjukkan bagaima ia sebagai perempuan Sunda yang memiliki pendidikan tinggi dan pada saat yang bersamaan juga mengabdi kepada suami dan anak. Hal ini terlihat pada kisah Ceu Popong ketika ia ditawarkan untuk mencalonkan diri sebagai Anggota DPR-RI, ia mengutamakan pertimbangan keluarga, bagaimana persetujuan anaknya dan bagaimana peran ia mengurus anaknya. Artinya, walaupun akan terjun dalam politik praktis, Ceu Popong tidak meninggalkan tanggung jawab dan perannya di keluarga (wilayah domestik).

Dalam perspektif gender dan feminis, dijelaskan dalam teori gender, gerakan feminis liberal berasumsi bahwa agar tercipta individu yang otonom dan independen haruslah didahului dengan terciptanya masyarakat yang adil, maka dari itu kesetaraan dan keadilan pada perempuan atas hak-haknya diperlukan untuk menunjang itu semua. Tujuan umum dari feminisme liberal adalah untuk menciptakan masyarakat yang adil dan peduli tempat kebebasan berkembang. Hanya di dalam masyarakat seperti itu, perempuan dapat mengembangkan diri sama seperti laki-laki. Ceu Popong sebagai politisi perempuan menunjukkan bahwa kesempatan yang diberikan kepadanya merupakan bagian dari keteraraan dengan laki-laki. Di mana ketika keadilan bagi masyarakat umum terwujud maka perempuan juga bisa mengembangkan dirinya. Dalam kasus Ceu Popong, ia telah terjun di dunia politik praktis bahkan sebelum Orde Reformasi, yaitu ketika rezim otoriter Soeharto masih berdiri. Eksistensi Ceu Popong di sebagai Anggota legislatif perempuan di dalam situasi politik yang otoriter bisa dikatakan sebagai anomali. Namun mengingat peran Ceu Popong sebagai istri prajutir TNI AD dan Ceu Popong juga merupakan perempuan dengan pendidikan tinggi maka tidak heran perempuan juga dapat mengembangkan dirinya di dalam politik praktis di dalam negara yang otoriter.

Pencalonan Ceu Popong sebagai Anggota DPR-RI merupakan suatu perubahan sosial yang dapat dianggap di luar norma yang berlaku saat itu. Ceu Popong sebagai individu yang memiliki berbagai kedudukan, yaitu sebagai perempuan, sebagai orang Sunda, seorang istri, dan seorang ibu, secara teoretis memiliki beban budaya dalam ketika berperan di ranah publik. Namun nyatanya hal tersebut tidak benar-benar terjadi. Budaya Sunda yang kental dalam diri Ceu Popong nyatanya tidak menjadi penghambat dalam perannya sebagai politisi di luar ranah domestik. 


\begin{tabular}{|c|c|c|c|c|}
\hline JURNAL & \multirow{2}{*}{ VOLUME 1 } & \multirow{2}{*}{ NOMOR 2 } & HALAMAN 70-141 & $\begin{array}{l}\text { ISSN 2655-8823 }(p) \\
\text { ISSN 2656-1786 }(e)\end{array}$ \\
\hline
\end{tabular}

Walau sebelumnya dijelaskan bahwa terjadi perbedaan perlakuan terhadap laki-laki dan perempuan dalam budaya Sunda. Hal ini disebabkan karena dalam keluarga Sunda selalu menempatkan ayah (laki-laki) sebagai kepala keluarga dan bertanggung jawab dalam keluarganya serta ayah merupakan pencari nafkah utama. Konstruksi peran perempuan Sunda sebagai pengurus keluarga memang terjadi dalam kasus Ceu Popong. Tetapi terjadi perubahan peran ketika peran domestik Ceu Popong tidak lagi dominan, yaitu ketika anak-anaknya sudah dewasa dan tidak bergantung lagi dengan sosok ibu. Perubahan itulah salah satunya yang menjadi pertimbangan utama Ceu Popong ketika mencalonkan diri sebagai Anggota DPR-RI.

Pemikiran Ceu Popong mengenai peran perempuan dan politik ia tuangkan dalam berbagai tulisan. Salah satunya dalam buku Antologi Karya Kumpulan Artikel Popong Otje Djundjunan yang ia tulis sendiri, Ceu Popong menceritakan bagaimana peran perempuan dalam masa revolusi kemerdekaan. Ketika itu peran perempuan masih sangat terbatas pada ranah domestik saja. Perempuan pada saat itu tidak berusaha secara langsung untuk berkompetisi dengan laki-laki, yang perepmuan lakukan adalah meingkatkan kemampuan, kecakapan, pengetahuan, agar dapat menjadi pasangan yang baik dalam rangka membangun keluarga, masyarakat, dan bangsa yang baik. Buku tersebut menjelaskan: ${ }^{25}$

"This absolutely essential if the women of Indonesia are to get the same opportunities as men, particularly in regard to education. The consequence of this opportunity to the women of Indonesia in this strategic era of development requires they play dualrole: being the head of household and/or mother in the home activities; and being the member of the society and citizen (public minded) involved in

25 Popong Otje Djundjunan, Ontologi Karta Kumpulan Artikel Popong Otje Djundjunan (Jakarta: 2018), h. 184-185 organizations and business with careers of their own"

"Hal ini sangat penting apabila perempuan Indonesia ingin mendapatkan kesempatan yang sama dengan lak-laki, terutama dalam bidang pendidikan. Konsekuensi dari kesempatan ini bagi perempuan Indonesia di era perkembangan strategis ini mengharuskan perempuan memainkan peran ganda: mengurusi rumah tangga dan/atau sebagai ibu di rumah; dan sebagai anggota masyarakat dan warga negara (di ranah public) terlibat dalam organisasi dan bisnis dengan karir mereka sendiri."

Pendidikan juga menjadi aspek yang penting dalam perspetif feminis maupun dalam kehidupan Ceu Popong. Aliran feminis liberal dari Wollstonecraft juga menitik beratkan pendidikan sebagai aspek pemberdayaan perempuan. Dengan didapatkannya akses pendidikan bagi perempuan maka perempuan seyogyanya bisa mandiri dari lakilaki, hal ini menurut dapat menjauhkan diri dari orang yang memandang perempuan hanya sebatas objek bukan manusia yang mempunyai nilai lebih. Pentingnya pendidikan juga terlihat dari bagaimana Ceu Popong selalu mengutamakan belajar. Tidak hanya belajar secara formal di sekolah, Ceu Popong juga gemar membaca dan banyak bertanya kepada politisi lain yang lebih senior darinya. Kesadaran akan pendidikan dan pengetahuan ini yang juga membuka akses Ceu Popong menjadi politisi. Aspek pendidikan Ceu Popong juga membuktikan bahwa pendidikan berperan paling dominan dalam pemberdayaan perempuan.

\section{PEMIKIRAN HARMONI BANGSA}

Pengalaman selama 5 periode sebagai Anggota DPR-RI menjadikan Ceu Popong salah satu politisi di Parlemen yang paling berpengalaman. Selama masa jabatannya di 


\begin{tabular}{|c|c|c|c|c|}
\hline JURNAL & \multirow{2}{*}{ VOLUME 1 } & \multirow{2}{*}{ NOMOR 2 } & HALAMAN 70-141 & $\begin{array}{l}\text { ISSN 2655-8823 }(p) \\
\text { ISSN 2656-1786 }(e)\end{array}$ \\
\hline
\end{tabular}

Parlemen, Ceu Popong sudah banyak menghadapi bebagai konflik kepentingan dari berbagai kelompok. Berbagai perbedaan dalam lingkungan politik nasional membuat Ceu Popong memberi perhatian lebih berkaitan dengan persatuan dan harmoni bangsa secara umum. Dalam menjaga harmoni bangsa, pertama kita perlu memahami makna harmoni. Menurut Ceu Popong, dalam Bahasa Sunda, harmoni dapat diartikan sebagai nurub сири tеи pasalia. Nurub сири merupakan pribahasa dalam Bahasa Sunda yang berarti serasi, sedangkan teu pasalia berarti tidak berbeda. Secara kontekstual nurub сири teu pasalia berarti serasi atau selaras. Dalam wawancara yang dilakukan penulis, Ceu Popong mengatakan: ${ }^{26}$

"Nah, sangat penting harmoni ini untuk bangsa kita. Karena bangsa kita terdiri dari 400 lebih suku bangsa. Terdiri dari sekian macam agama. Terdiri dari sekian macam etnis. Terdiri dari sekian juta macam budaya. Dapat dibayangkan oleh kita kalau yang Ceu Popong sebut tadi semua itu tidak harmoni. Kebayang kan tidak yang 400 suku bangsa lebih kemudian itu bertentangan? Baru dua (suku) juga kalau tidak harmoni mah pasti tidak akan nyetrum. Nah, sekian macam agama, tidak ada jalan lain untuk bangsa kita itu, yaitu memunculkan, mewujudkan kata harmoni menjadi kenyataan. Bukan hanya diucapkan, tapi harus jadi kenyataan. Siapa yang melaksanakan? (kita) Sama-sama."

Setelah sepakat dalam memaknai harmoni, baru kita dapat mengamalkan apa saja ajaran dan filosofi untuk mewujudkan harmoni. Secara khusus Ceu Popong menyebutkan filosofi Sunda sauyunan, silih asah, silih asih, silih asuh, silih aping, silih geuing, silih ajenan. Saayunan berarti sehati, silih asah berarti saling mengingatkan, silih asih berarti saling mengasihi, silih asuh berarti saling membimbing, silih geuing artinya saling membangun, silih ajenan

\footnotetext{
26 Wawancara dengan Ceu Popong, dilakukan di Bandung pada Senin, 29 Juli 2019
}

artinya saling menghargai. Menurut $\mathrm{Ceu}$ Popong, orang Sunda sudah seharusnya paham filosofi Sunda. Filofosi Sunda mengenai harmoni sudah sangat gambling, silih asah, silih asih, silih asuh, silih aping, silih geuing, silih ajenan bisa berlaku universal, tidak hanya berlaku untuk orang Sunda.

Menganal dan mengamalkan filosofi budaya daerah, khususnya budaya Sunda bukan berarti mengkotak-kotakkan suku bangsa, tetapi justru menunjukkan jati diri bangsa. Tidak mungkin kita memelihara budaya kita itu dengan maksud yang negatif yaitu untuk mengkotak-kotakkan. Memang kewajiban dari setiap suku bangsa itu memelihara budayanya sendiri sambil kita menghargai keberadaan budaya suku bangsa lain. Memelihara budaya sendiri sambil menghargai juga keberadaan budaya lain. Menurutnya, kalau kita hanya ngeukeuweuk (mendekap) budaya sendiri sambil tidak menghargai budaya lain akan buruk bagi persatuan bangsa.

Bagi Ceu Popong, melestarikan budaya asli daerah dan menjunjung tinggi persatuan dan nasionalisme bukan merupakan suatu paradox. Dalam pengalamannya sebagai politisi di tingkat nasional, Ceu Popong harus menjunjukkan identitas sebagai orang Sunda. Orang lain harus tahu bahwa Ceu Popong adalah orang Sunda, bukan suku lain. Jangan menganggap diri paling bagus atau paling benar, begitupun dalam konteks politik. Sekalipun Ceu Popong merupakan politisi partai Golkar sejak tahun 1960an, tapi tidak merasa sebagai partai paling hebat.

"Keberadaan dunia politik kita pelihara sambil kita menghargai keberadaan lingkaran politik yang lain. Dan itu akan terlihat pada saat kita ada di DPR. Kita menghargai keberadaan merah kuning hijau di langit yang biru (sambil bernyanyi)."

Menghargai orang lain adalah salah satu cara untuk menghargai diri sendiri. Begitupun dalam pergaulan di dunia politik. 


\begin{tabular}{|c|c|c|c|c|}
\hline JURNAL & \multirow{2}{*}{ VOLUME 1 } & \multirow{2}{*}{ NOMOR 2 } & HALAMAN 70-141 & $\begin{array}{l}\text { ISSN 2655-8823 }(p) \\
\text { ISSN 2656-1786 }(e)\end{array}$ \\
\hline
\end{tabular}

Jaga lingkaran politik kita dalam partai sambal menghargai lingkaran politik orang lain. Rasa saling menghargai ini akan terasa langsung ketika kita berada di DPR-RI dengan berbagai orang dari berbagai latar belakang.

Peran Ceu Popong sebagai politisi Partai Golkar tidak membuatnya mengeksklusifkan identitasnya sebagai anggota partai maupun sebagai keturunan Sunda. Perbedaan suku budaya dan dalam konteks politik dalam partai tidak sepatutnya dibenturkan. Bagi Ceu Popong, ketika sudah menjadi Anggota DPR maka harus memperjuangkan kepentingan semua rakyat, bukan kepentingan partai. Sebagai anggota partai memang sudah sewajarnya mengikuti arahan partai di internal, tetapi perannya di dalam DPR tetap sebagai perwakilan rakyat. Sehingga keberhasilannya sebagai perempuan Sunda yang menjadi anggota DPR-RI dari partai Golkar menjadi modal awal untuk memperjuangkan kepentingan yang lebih luas. Mengenai hal ini Ceu Popong bercerita ketia ia diwawancara dalam acara TV Mata Najwa sebagai calon anggota DPRRI periode 2014-2019 yang akan dilantik pada 1 Oktober 2014. Dalam wawancara itu ia ditanya apa yang akan dilakukannya sebagai anggota DPR, Ceu Popong menjelaskan:

"yang pertama istilahnya atau fungsinya adalah selaku anggota Dewan Perwakilan Rakyat. DPR, bukan dewan perwakilan partai. Jadi, begitu dilantik (pada) 1 Oktober, tidak hanya memperjuangkan warna partai kita. Tapi memperjuangkan semua warna. Begitu kita terjun ke masyarakat kita tidak boleh lagi membeda-bedakan warna. Semua warna kita perjuangkan kepentingannya. Karena rakyat itu membutuhkan Dewan Perwakilan Rakyat, bukan membutuhkan dewan perwakilan partai. Kalau sudah berpikiran seperti itu, kita terjun kapanpun, di manapun, menghadapi siapapun, perjuangan kita akan tetap. Yang penting itu. Kalo sudah seperti itu ya Insya Allah. Semua akan (ber)tanggung jawab."
Harmoni kebangsaan dalam pengalaman Ceu Popong sebagai anggota DPR-RI ia analogikan seperti lagu Pelagi-pelangi yang memiliki banyak warna yang membuatnya indah dipandang. Seperti halnya suku bangsa yang berbeda-beda dan warna partai yang berbeda-beda seharusnya menciptakan harmoni dan kesatuan, bukan saling menjatuhkan. Seperti yang dikatakan Ceu Popong:

"Warnana teh koneng hungkul (warnanya kuning saja). Bereum we hungkul (merah ya merah saja). Pan tidak akan indah. Merah kuning hijau di langit yang biru (bernyanyi). Nah keindahannya adalah seperti itu."

Perbedaan identitas gender, laki-laki dan perempuan, perbedaan suku, dan perbedaan partai seharusnya tidak menjadi alat pemecah bangsa. Ketika sudah bekerja sebagaianggota DPR-RI perbedaan itu harusnya dihilangkan dan bekerja untuk semua rakyat dari semua golongan. Identitas sebagai seorang perempuan bukan merupakan identitas yang inferior dibandingkan laki-laki. Ceu Popong berpesan, jangan merasa rendah diri atas identitas dirinya. Hal yang harus diutamakan sebagai anggota parmelen adalah kemampuannya, bukan identitas kesukuan atau gender. Ceu Popong menjelaskan, parlemen dari kata parle yang artinya berbicara. Maksudnya adalah, sebagai anggota parlemen harus punya kemampuan untuk menyampaikan sesuatu; untuk menjelaskan sesuatu; untuk memperjuangkan sesuatu; untuk mengusulkan sesuatu dengan kemampuan bicaranya.

Bagaimana kita memperjuangkan kepentingan-kepentingan rakyat dengan cara parle (bicaraI). Wakil rakyat di parlemen harus berbicara dan mengutarakan gagasannya dengan percaya diri. Apabila seorang anggota parlemen tidak percayaq diri dan tidak memiliki kemampuan bcara yang baik maka walau memiliki gagasan yang baik tetapi penyampaiannya tiak akan sesuai. Bakat dan kemampuan seseorang, terlepas dari gender, suku, agama, dan latar belakang, harus diasah. 
"Tidak ada orang yang instan ujug-ujug (tiba-tiba) pintar bicara. Tidak ada. Ujugujug terampil. Tidak ada. Ujug-ujug disiplin; ujug-ujug (memiliki) tanggung jawab. Berbicara dengan maksud memperjuangkan rakyat yang diwakili. Walaupun maksud kita baik, otak kita encer, gelar S1, S2, ada S3. Tapi kita tidak punya kemampuan untuk menyampaikannya dalam kata-kata, mungkin hasilnya tidak akan maksimal."

Kemampuan seorang politisi dan anggota DPR-RI tidak hanya dari pendidikan formalnya saja, tetapi dari kecakapanj dia berbicara. Dalam berbicara kita harus memiliki ilmunya agar substansi yang sampaikan berkualitas. Oleh karena itu, banyak membaca adalah salah satu kuncinya. Selain itu Ceu Popong berpesan agar banyak bertanya dan mendengar. Dengan banyak bertanya dan mendengarkan, selain salah satu cara untuk memperkaya ilmu, juga sebagai cara untuk menghargai pendapat orang lain. Sehingga, ketika seorang anggota parlemen bicara, tidak tong kosong nyaring bunyinya.

Menjaga lisan juga slah satu hal yang diingatkan Ceu Popong dalam menjaga harmoni dan relasi. Dalam memperkaya ilmu, kita harus banyak membaca, bertanya, mendengar, dan melihat, tetapi ketika sudah berbicara dan bertindak kita harus sesuai dengan tugas yang kita miliki. Tugas parlemen adalah menyampaikan gagasan, ide, usul, saran kepada kepada pemerintah. Karena rekan kerja parlemen adalah pemerintah atau eksekutif, yaitu Presiden, kabinetnya, dan badan-badan di bawah. Pemerintah adalah pelaksana teknisnya, sedanghkan DPR bertugas memperjuangkan aspirasi rakyat yang nanti menjadi kebijakannya berupa Undang-Undang.

Sedangkan upaya menjaga harmoni bangsa sebagai rakyat di kehidupan seharihari, Ceu Popong menjelaskan, apapun kedudukan seseorang dan seberapa banyak kekayaannya, bentuk menjaga hermoni bangsa yang paling sederhana adalah dengan mengenal tetangga di lingkungan RT (Rukun Tetangga). Menurut Ceu Popong, lingkungan
RT merupkaan analogi dari pemerintahan Indonesia. Dalam organisasi RT terdapat ketua RT, sekretaris RT, dan bendahara RT. Selain mengenal tetangga kita juga harus menghargai perangkat RT tersebut. Walau, misalnya seorang ketua RT usianya lebih muda atau memiliki tingkat ekonomi lebih rendah, harus tetap kita hargai. Kalau masyarakat dalam tingkatan RT sudah saling mengenal dan saling menghargai maka harmoni bisa terwujud.

Pada akhirnya, menjaga harmoni bangsa adalah tugas semua orang. Ceu Popong sebagai anggota DPR-RI, memiliki tuga untuk memperjuangkan kepentingan rakyat terlepas dari identitas dan latar belakangnya. Seorang politisi harus memiliki pengetahuan dengan banyak membaca, bertanya, mendengar dan melihat agar dapat mamahami apa yang ingin dia perjaungkan. Selain itu, seorang anggota DPR harus bersikat sesuai dengan tugasnya. Di sisi lain, seorang rakyat juga bisa mewujudkan harmoni bangsa dari tingkat terkecil yaitu tingkat RT dengan saling mengenal dan saling menghargai satu sama lain.

\section{KESIMPULAN}

Sosok Ceu Popong sebagai perempuan Sunda yang berhasil menduduki kursi sebagai Anggota DPR-RI memberi banyak pelajaran mengenai budaya, gender, dan kebangsaan. Perempuan Sunda yang kental dengan budaya partriartinya ternyata tidak menjadi halangan bagi Ceu Popong untuk menjadi politisi. Keberhasilan Ceu Popong ini justru tidak terlepas dari berbagai filosofi budaya Sunda iya pahami. Di antara filosofi Sunda yang diamalkan Ceu Popon di antaranya "silih asah silih asih silih asuh." Silih asah, saling menajamkan pikiran atau saling mengingatkan. Silih asih, saling mengasihi.

Silih asuh, saling mengasuh atau saling membimbing. Selain itu, Ceu Popong memberikan beberapa pelajaran yang ia amalkan dari budaya Sunda yaitu nyantri (belajar agama), nyakola (belajar, tidak hanya di sekolah), dan tidak membangga- 


\begin{tabular}{|c|c|c|c|c|}
\hline JURNAL & \multirow{2}{*}{ VOLUME 1 } & \multirow{2}{*}{ NOMOR 2 } & HALAMAN 70-141 & $\begin{array}{l}\text { ISSN 2655-8823 }(p) \\
\text { ISSN 2656-1786 }(e)\end{array}$ \\
\hline
\end{tabular}

banggakan kesukuan untuk membangun harmoni kebangsaan.

Kebudayaan tidak bisa dilepaskan dari konstruksi gender. Budaya Sunda yang merupakan budaya bilateral, memiliki beragam filosofi dalam memandang kedudukan perempuan, ada yang memandangnya tinggi, setara, maupun di bawah. Ceu Popong sebagai perempuan asli Sunda nyatanya tidak banyak terpengaruh dengan kedudukan perempuan Sunda ketika terjun dalam dunia politik. Ceu Popong dapat menempatkan diri sebagai perempuan di wilayah domestik dengan mengurus keluarga, tetapi juga dapat mengembangkan diri di luar wilayah domestik dengan menjadi politisi. Perubahan peran Ceu Popong ini dari perspektif gender menunjukkan bagaimana pentingnya pendidikan untuk membuka akses pemberdayaan perempuan. Selain itu, perubahan peran Ceu Popong juga tidak terlepas dari dukungan keluarga dan lingkugan sekitarnya.

Dalam konteks menjaga harmoni bangsa, identitas gender dan suku seharusnya tidak menjadi penghalang bagi persatuan bangsa. Ceu Popong sebagai anggota DPR-RI, memiliki tuga untuk memperjuangkan kepentingan rakyat terlepas dari identitas dan latar belakangnya. Seorang politisi harus memiliki pengetahuan dengan banyak membaca, bertanya, mendengar dan melihat agar dapat mamahami apa yang ingin dia perjaungkan. Selain itu, seorang anggota DPR harus bersikat sesuai dengan tugasnya. Di sisi lain, seorang rakyat juga bisa mewujudkan harmoni bangsa dari tingkat terkecil yaitu tingkat RT dengan saling mengenal dan saling menghargai satu sama lain. Pada akhirnya, menciptakan harmoni dan persatuan bangsa merupakan tugas kita semua.

\section{DAFTAR PUSTAKA}

Ajip Rosyidi, Masa Depan Budaya Daerah: Kasus Bahasa Sunda dan Sejarah Sunda. Jakarta. PT Dunia Pustaka Jaya. 2004.

Djundjunan, Popong Otje, Autobiografi Popong Otje Djundjunan. Jakarta: 2019.
Djundjunan, Popong Otje, Ontologi Karta Kumpulan Artikel Popong Otje Djundjunan. Jakarta. 2018.

Edi S. Ekadjati, Kebudayaan Sunda: Suatu Pendekatan Sejarah Jiid 1. Jakarta. PT Dunia Pustaka Jaya. 2009.

Hartono dan Arnicun Aziz, Ilmu Sosial Dasar. Jakarta. Bumi Aksara. 2008.

Ian Adams, Ideologi Politik Mutakhir: Konsep, Ragam, Kritik, dan Masa Depannya. Yogyakarta. Qalam. 2004.

Ida Rosyidah dan Hermawati, Relasi Gender dalam Agama-Agama. Jakarta. UIN Jakarta Press. 2003.

Mansour Fakih, Analisis Gender dan Transformasi Sosial. Yogyakarta.

Pustaka Pelajar. 1997.

Marlina, Hj. Ietje, "Kedudukan Wanita Menak Dalam Struktur Masyarakat Sunda: Studi Kasus di Kota Bandung," Sosiohumaniora, Vol. 8, No. 2, Juli 2006

Raja Eben Lumbanrau, "Ceu Popong Dukung Putusan Mendikbud Muhadjir Hapus UN 2017," CNN Indonesia, 25 November 2016, diakses dari https://www.cnnindonesia.com/nasional/ 20161125160746-20-175295/ceupopong-dukungputusan-mendikbudmuhadjir-hapus-un-2017, diakses pada 5 Juli 2019.

Rosemarie Putnam Tong, Feminist Thought: Pengantar Paling Komprehensif kepada Aliran Utama Pemikiran Feminis. Yogyakarta. Jalasutra. 2004.

Soerjono Soekanto, Teori Sosiologi tentang Pribadi dalam Masyarakat. Jakarta. Ghalia Indonesia. 1984.

Tanpa nama penulis, "Ceu Popong Raih Penghargaan ke-506," PRFMNews.com, 11 Februari 2017, http://www.prfmnews.com/berita.php?d etail=ceu-popong-raihpenghargaanke506, diakses pada 5 Juli 2019.

Tanpa nama penulis, "Dra. Popong Otje Djundjunan," Dewan Perwakilan Rakyat Republik Indonesia, http://www.dpr.go.id/anggota/detail/id/1 $\underline{00}$ 


\begin{tabular}{|c|c|c|c|c|}
\hline JURNAL & \multirow{2}{*}{ VOLUME 1} & NOMOR 2 & HALAMAN 70-141 & $\begin{array}{l}\text { ISSN 2655-8823 }(p) \\
\text { ISSN 2656-1786 }(e)\end{array}$ \\
\hline
\end{tabular}

Tanpa nama penulis, "Kisah Ceu Popong tolak menteri pidato bahasa asing," Merdeka.com, 2 Oktober 2014, https://www.merdeka.com/peristiwa/kis ah-ceu-popong-tolakmenteri-pidatobahasa-asing.html, diakses pada 5 Juli 2019.

Tanpa nama penulis, "Panggilan kepada kakak perempuan," Kamusdaerah.com, https://www.kamusdaerah.com/?bhs=a\& bhs $2=$ m\&q=panggilan $\% 20 \mathrm{kepada} \% 20 \mathrm{k}$ akak\%20perempuan, diakses pada 5 Juli 2019.

Tanpa nama penulis, "Popong Otje Djundjunan", Merdeka.com, https://m.merdeka.com/popong-otjedjundjunan/profil//, diakses pada 5 Juli 2019.

Warsito, Antropologi Budaya, Cet II. Yogyakarta. Ombak, 2015.

Wawancara pertama langsug dengan $\mathrm{Ceu}$ Popong, dilakukan di Bandung, pada Jumat, 21 Juni 2019.

Wawancara kedua langsug dengan Ceu Popong, dilakukan di Bandung, pada Senin, 29 Juli 2019. 